\title{
PEMANFAATAN TEKNOLOGI INFORMASI DAN KOMUNIKASI (TIK) UNTUK PEMBELAJARAN DI SMP NEGERI 5 PONOROGO, JAWA TIMUR
}

\section{Utilization of Information and Communication Technologies (ICT) for Learning in SMPN 5 Ponorogo, East Java}

\author{
Arie Kurniawan \\ Balai Pengembangan Media Radio Pendidikan dan Kebudayaan (BPMRPK) \\ Kementerian Pendidikan dan Kebudayaan (Kemendikbud) \\ Jl. Sorowajan Baru Nomor 367, Banguntapan, Bantul, Yogyakarta, Indonesia \\ arie.kurniawan@kemdikbud.go.id
}

\begin{abstract}
ABSTRAK: Saat ini, penggunaan Teknologi Informasi dan Komunikasi (TIK) untuk membantu proses pembelajaran merupakan suatu hal yang biasa. Penelitian ini bertujuan untuk mengetahui bagaimana pemanfaatan TIK dalam pembelajaran di SMPN 5 Ponorogo. Hal-hal yang dipehatikan meliputi peralatan yang digunakan, frekuensi pemanfaatan, hambatan yang dihadapi, dukungan dari pemimpin, serta pengaruhnya terhadap motivasi belajar siswa. Objek dari penelitian ini adalah 51 orang guru di SMPN 5 Ponorogo. Penelitian ini menggunakan metode survei dengan instrumen kuesioner dan wawancara. Data yang diperoleh kemudian dianalisis secara deskriptif kuantitatif. Hasil penelitian menyatakan bahwa seluruh responden sudah memanfaatkan TIK dalam proses pembelajaran meskipun dengan frekuensi yang berbeda-beda. Hambatan yang dihadapi antara lain adalah keterbatasan sarana serta rendahnya kemampuan memanfaatkan TIK. Meskipun literasi digitalnya masih rendah, seluruh guru memiliki semangat belajar yang tinggi sehingga kemampuannya bisa ditingkatkan melalui pelatihan-pelatihan. Pemanfaatan TIK juga terbukti mampu meningkatkan motivasi belajar siswa dan berdampak juga terhadap prestasi belajar mereka. Guna meningkatkan kualitas pembelajaran yang memanfaatkan TIK, pihak sekolah perlu meningkatkan kualitas perangkat TIK. Selain itu, perlu juga dilakukan pelatihan guna meningkatkan kemampuan guru dalam memanfaatkan TIK untuk mendukung proses pembelajaran.
\end{abstract}

Kata Kunci: TIK, Motivasi, Pembelajaran

ABSTRACT: Currently, the use of Information and Communication Technology (ICT) to help the learning process is a common thing. This research aims to find out how the utilization of ICT for learning in SMPN 5 Ponorogo is. The concern includes the utilized-equipment, the utilization frequency, faced-obstacles, support from the leaders, and the impcat on the students' learning motivation. The object of this research is 51 teachers in SMPN 5 Ponorogo. This research uses survey method with questionnaire and interview instrument. The data obtained are analyzed descriptively 
quantitatively. The research result states that all respondents have utilized ICT in their learning process although with different frequency. Obstacles encountered include limited facilities and low ability to utilize ICT. Despite their low digital literacy, all teachers have high learning spirit so that their skills can be improved through trainings. ICT utilization also proves to be able to increase students' learning motivation and also impact their learning achievement. To improve the quality of learning process that utilizes ICT, the schools need to improve the quality of ICT equipment. In addition, some relevant training are also necessary to improve the teachers' ability in utilizing ICT to enhance the learning process.

Keywords: ICT, Motivation, Learning Activity

\section{PENDAHULUAN}

Perkembangan Teknologi Informasi dan Komunikasi (TIK) diawali pada era media cetak, di mana pada saat itu orang memperoleh informasi melalui media cetak berupa surat kabar. Ide munculnya surat kabar ini terjadi pada masa Romawi kuno dan masih bertahan hingga saat ini, di saat teknologi digital berkembang dengan pesat. Perkembangan TIK selanjutnya berupa penggunaan teknologi pengiriman serta penerimaan sinyal suara atau lebih kita kenal dengan istilah media radio. Teknologi radio ini pertama kali digunakan untuk kepentingan militer, yaitu untuk mengirimkan pesan antara kapal dengan darat. Perkembangan TIK selanjutnya memasuki tahapan media audio visual, yaitu dengan ditemukannya televisi. Perkembangan televisi dimulai dari yang paling sederhana yaitu televisi mekanik hingga yang paling mutakhir adalah televisi satelit. TIK mengalami kemajuan yang pesat semenjak ditemukannya komputer serta terkoneksinya komputer tersebut dengan jaringan internet, hingga saat ini, di mana manusia sudah sangat terbantu dengan adanya smartphone (Reynold dan Rosul, 2010).

TIK sendiri bisa didefinisikan sebagai segala kegiatan yang terkait dengan pemrosesan, manipulasi, pengelolaan, dan pemindahan informasi antar media (Dewi dan Hilman, 2018). Pemanfaatan TIK dalam pembelajaran identik dengan sebutan elearning. E-learning merupakan sebuah sistem pendidikan yang memanfaatkan TIK dalam proses pembelajarannya (Warsihna, 2012). Saat ini, penerapan e-Learning merupakan suatu hal yang tidak bisa dihindari lagi demi meningkatkan kualitas pembelajaran. Pembelajaran yang dirancang dan dikembangkan dengan menggunakan teknologi pembelajaran akan mampu meningkatkan kualitas pembelajaran karena para siswa memperoleh layanan yang optimal sesuai dengan karakteristik serta gaya belajar mereka masing-masing sehingga mereka merasa lebih senang, aktif, dan mudah dalam belajar (Ismaniati, 2010).

Proses pembelajaran hendaknya berorientasi kepada peran aktif siswa, dengan kata lain, pembelajaran merupakan suatu proses aktif. Sejalan dengan perkembangan TIK, proses pembelajaran di sekolah hendaknya dirancang dengan memanfaatkan TIK. Peran TIK dalam pembelajaran aktif cukup signifikan, sebab TIK mampu membantu jalannya pembelajaran aktif (Warsihna, 2013). Salah satu faktor pendukung keberhasilan pemanfaatan TIK dalam pembelajaran di sekolah terletak pada kebijakan dari kepala sekolah selaku pemimpin organisasi. Setiap kebijakan yang diambil oleh kepala sekolah sangatlah berpengaruh terhadap mutu dan kualitas pembelajaran di sekolah. Kepala sekolah sebagai pemimpin memiliki peran yang dominan dalam sebuah organisasi, peran yang menentukan kualitas serta prestasi organisasi yang dipimpinnya (Triyanto dkk, 2013). 
Adapun pendayagunaan TIK dalam pembelajaran memiliki beberapa manfaat, yaitu antara lain: 1) memperluas akses pendidikan; 2) meningkatkan kompetensi peserta didik; 3) meningkatkan kualitas pembelajaran; dan 4) meningkatkan transformasi lingkungan belajar (Wijaya, 2007).

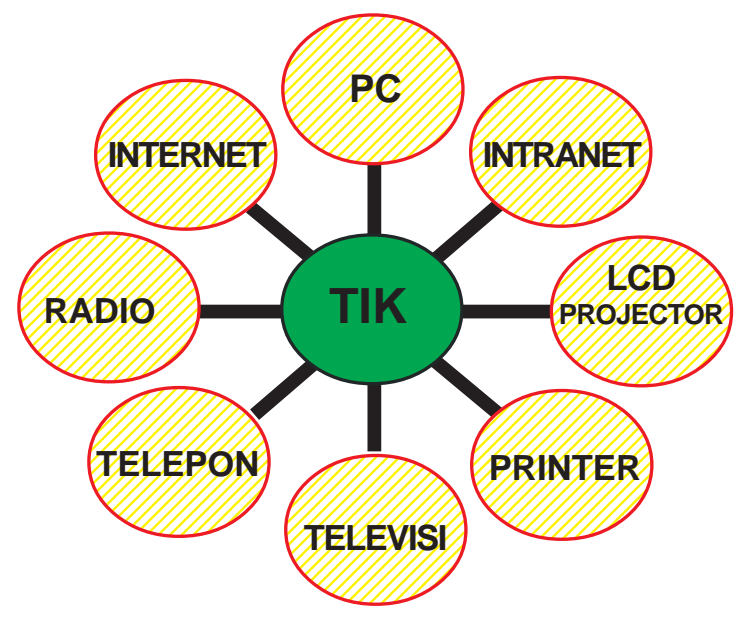

Gambar 1. Perangkat TIK (Siahaan, 2009)

Perangkat TIK terdiri dari dua hal, yaitu perangkat keras atau hardware dan perangkat lunak atau software. Perangkat keras merupakan segala macam peralatan teknologi yang berbentuk fisik, sedangkan perangkat lunak merupakan sistem yang menjalankan atau berjalan pada perangkat keras tersebut (Siahaan, 2009). Dengan kata lain, perangkat keras merupakan benda fisik yang bisa dilihat dan disentuh, sedangkan perangkat lunak merupakan program yang tidak kasat mata.

Berkaitan dengan uraian di atas, bagaimanakah pemanfaatan TIK untuk pembelajaran di sekolah, khususnya di SMPN 5 Ponorogo? Hingga saat ini, belum pernah diadakan penelitian mengenai pemanfaatan TIK untuk pembelajran di SMPN 5 Ponorogo. Penelitian ini bertujuan untuk mengetahui bagaimana pemanfaatan TIK dalam pembelajaran di SMPN 5 Ponorogo mulai dari perangkat yang digunakan, frekuensi pemanfaatan dalam 1 minggu, hambatan yang dihadapi, hingga pengaruhnya terhadap motivasi belajar siswa. Motivasi merupakan kekuatan diri seseorang yang dapat menimbukan tingkat persistensi dalam melakukan suatu kegiatan, baik yang bersumber dari dalam diri individu maupun dari luar individu (Sudrajat, 2008). Persistensi sendiri merupakan suatu tindakan yang dilakukan secara sukarela oleh seorang individu dalam rangka mencapai sesuatu yang diinginkan meskipun dalam melakukan tindakan tersebut menemui berbagai hambatan dan kesulitan. Motivasi memiliki peran yang cukup besar dalam menentukan hasil belajar siswa. Penelitian yang dilakukan oleh Alimuddin S. Miru menyatakan bahwa motivasi belajar mempengaruhi prestasi belajar sebesar $12,4 \%$, dan selebihnya adalah faktor lain meliputi gaya belajar, fasilitas belajar, ruangan belajar, dan lainnya (Miru, 2009).

Penelitian ini dilakukan hanya untuk mengetahui tentang bagaimana pemanfaatan TIK di SMPN 5 Ponorogo dan pengaruhnya terhadap motivasi belajar siswa, belum sampai dengan pengaruhnya terhadap prestasi belajar siswa sehingga memungkinkan untuk diteliti lebih lanjut. Saat ini, seluruh guru di SMPN 5 Ponorogo sudah mengintegrasikan TIK dalam proses pembelajarannya. Hal ini tidak terlepas dari adanya kebijakan dari kepala sekolah yang mewajibkan pemanfaatan TIK dalam proses pembelajaran, baik di kelas maupun di luar kelas. Setiap guru menggunakan perangkat TIK yang berbeda-beda sesuai dengan materi pembelajaran yang disampaikan, mulai dari smartphone hingga laptop.

\section{METODA}

Penelitian ini dilaksanakan di SMPN 5 Ponorogo pada tanggal 14 hingga 15 September 2017. SMPN 5 Ponorogo merupakan salah satu sekolah binaan Pustekkom sebagai sekolah inovatif yang memanfaatkan TIK dalam pembelajaran (Pustekkom, 2016b). Mulai tahun 2016, SMPN 5 Ponorogo bersama 25 sekolah lainnya yang terdiri dari satuan pendidikan mulai dari SD, SMP, SMA serta pondok pesantren baik negeri maupun swasta dibina langsung oleh Pustekkom-Kemendikbud untuk melaksanakan proses pembelajaran dengan memanfaatkan portal rumah belajar 
sebagai bahan pembelajaran maupun sarana interaksi baik sebagian maupun secara menyeluruh (Pustekkom, 2016a). Pada tahun pertama, seluruh sekolah tersebut diberikan peralatan TIK penunjang pembelajaran yang berupa 33 buah laptop, 1 buah LCD Projector, 1 buah server serta beberapa perangkat pendukung lainnya. Tahun kedua, sekolah tersebut harus memanfaatkan peralatan yang sudah diberikan untuk mendukung proses pembelajaran. Di tahun ketiga yang merupakan tahun terakhir, sekolah harus mampu mendiseminasikan pembelajaran yang memanfaatkan TIK kepada sekolahsekolah lain di sekitarnya.

Instrumen yang digunakan dalam penelitian ini adalah kuesioner, di mana responden memberikan jawaban terhadap pertanyaan-pertanyaan yang diberikan. Selain itu, dilakukan juga wawancara dengan responden guna memperoleh keterangan lebih lanjut mengenai pemanfaatan TIK di SMPN 5 Ponorogo ini. Penelitian pemanfaatan TIK di SMPN 5 Ponorogo ini menggunakan teknik analisis data berupa analisis deskriptif, yaitu dengan cara mendeskripsikan kemudian memaknai data yang diperoleh.

\section{HASIL DAN PEMBAHASAN}

Responden dalam penelitian ini adalah 51 orang guru SMPN 5 Ponorogo yang memiliki usia, serta pengalaman mengajar yang bervariasi.

Tabel 1. Usia Guru

\begin{tabular}{lll}
\hline No & Usia & Reponden (orang) \\
\hline 1 & $<30$ tahun & 5 \\
\hline 2 & $30-40$ tahun & 3 \\
\hline 3 & $41-50$ tahun & 15 \\
\hline 4 & $>50$ tahun & 28 \\
\hline & Jumlah & $\mathbf{5 1}$ \\
\hline
\end{tabular}

Dari tabel 1 tentang usia guru, bisa dilihat bahwa 28 orang guru SMPN 5 Ponorogo atau sebesar $54,9 \%$ berusia di atas 50 tahun; sebanyak 15 orang atau $29,4 \%$ berusia antara 41 hingga 50 tahun; dan 8 orang atau 15,7\% saja yang berusia 40 tahun atau kurang.
Tabel 1 di atas menunjukkan bahwa sebagian besar responden tergolong ke dalam kaum Digital Immigrants, yaitu mereka yang lahir sebelum era digital, namun pada perkembangannya memiliki ketertarikan dan memanfaatkan teknologi digital (Prensky, 2001). Namun demikian, hasil wawancara menunjukkan bahwa para responden memiliki semangat dan kemauan yang kuat untuk mempelajari dan memanfaatkan teknologi untuk keperluan pembelajaran, meskipun mereka lahir di saat teknologi belum marak digunakan. Sebuah semangat yang perlu kita apresisasi mengingat usia mereka yang terbilang sudah tidak muda lagi.

Selain memiliki usia yang cukup beragam, responden juga memiliki pengalaman mengajar yang beragam pula, sebagaimana terlihat dari Tabel 2 berikut ini.

Tabel 2. Pengalaman Mengajar

\begin{tabular}{llc}
\hline No & Pengalaman Mengajar & Responden (orang) \\
\hline 1 & $<10$ tahun & 7 \\
\hline 2 & $10-20$ tahun & 10 \\
\hline 3 & $20-30$ tahun & 26 \\
\hline 4 & $>30$ tahun & 8 \\
\hline & Jumlah & $\mathbf{5 1}$ \\
\hline
\end{tabular}

Menurut tabel 2 mengenai pengalaman mengajar, sebagian besar responden memiliki pengalaman mengajar yang relatif cukup tinggi. Lebih dari $60 \%$ responden memiliki pengalaman mengajar lebih dari 20 tahun, yang artinya sudah tidak diragukan lagi pengalamannya. Pengalaman mengajar sendiri merupakan salah satu faktor yang turut menentukan kompetensi mengajar guru. Sebagaimana penelitian yang dilakukan oleh Dr. S. Eko Putro Widoyoko, M.Pd, guru dengan pengalaman mengajar tinggi mempunyai kompetensi mengajar yang tinggi pula (Widoyoko, 2009). Guru dengan pengalaman mengajar yang tinggi tentu saja memiliki banyak pengalaman dalam membelajarkan siswa. Mereka memiliki banyak pengalaman menghadapi berbagai macam karakteristik, gaya belajar siswa, dan hambatan dalam proses pembelajaran. Guru 
dengan pengalaman mengajar tinggi biasanya mampu beradaptasi dengan situasi dan kondisi baru, termasuk juga adaptasi dengan pemanfaatan TIK untuk pembelajaran.

Seluruh responden atau sebanyak 51 orang menyatakan telah memanfaatkan TIK dalam proses pembelajarannya, baik itu untuk pembelajaran di kelas maupun di luar kelas. Pembelajaran di luar kelas meliputi juga pemberian tugas kepada siswa untuk mencari referensi dari internet terkait dengan materi pembelajaran. Adapun frekuensi pemanfaatan TIK dalam pembelajaran di SMPN 5 Ponorogo ini cukup beragam, seperti terlihat dalam Tabel 3 berikut ini.

Tabel 3. Frekuensi Pemanfaatan TIK dalam Seminggu

\begin{tabular}{lll}
\hline No & $\begin{array}{l}\text { Frekuensi pemanfaatan } \\
\text { TIK (dalam 1 minggu) }\end{array}$ & $\begin{array}{l}\text { Responden } \\
\text { (orang) }\end{array}$ \\
\hline 1 & $<5$ kali & 46 \\
\hline 2 & $5-10$ kali & 4 \\
\hline 3 & $>10$ kali & 1 \\
\hline & Jumlah & $\mathbf{5 1}$
\end{tabular}

Berdasarkan tabel di atas, bisa dilihat bahwa sebagian besar guru di SMPN 5 Ponorogo, yaitu sebanyak 46 orang, memanfaatkan TIK dalam proses pembelajaran kurang dari 5 kali dalam seminggu. Ada 4 orang guru yang selama seminggu memanfaatkan TIK dalam proses pembelajaran sebanyak 5 hingga 10 kali, dan hanya ada 1 orang guru yang memanfaatkan TIK dalam proses pembelajaran lebih dari 10 kali seminggu. Berdasarkan wawancara dengan para responden, mereka menyatakan bahwa frekuensi pemanfaatan TIK dalam proses pembelajaran ini bersifat fleksibel tergantung kepada topik yang dipelajari oleh siswa. Ada topik yang lebih mudah dipelajari oleh siswa ketika guru menggunakan bantuan TIK dalam pembelajaran, namun ada juga topik yang tidak memerlukan penggunaan TIK. Hal itulah yang menjadikan frekuensi pemanfaatan TIK ini menjadi fleksibel disesuaikan dengan kebutuhan dan tujuan pembelajaran yang hendak dicapai.

\section{Perangkat TIK Pendukung Pembelajaran}

Berdasarkan hasil penelitian, perangkat keras yang digunakan oleh guru-guru di SMPN 5 Ponorogo adalah komputer, laptop, televisi, LCD Projector, radio, smartphone, kamera digital, pemutar video, pengeras suara, dan masih banyak lagi lainnya. Kebalikan dari perangkat keras, perangkat lunak tidak bisa dilihat secara fisik namun nyata keberadaannya, misalnya Operating System (OS), aplikasi, koneksi internet serta program-program lainnya. Perangkat lunak yang digunakan oleh para guru di SMPN 5 Ponorogo antara lain adalah aplikasi pengolah perkantoran Microsoft Office, kemudian aplikasi pembuat animasi seperti Macromedia Flash, serta aplikasi pembuat soal seperti Quiz Creator. Proses pembelajaran di SMPN 5 Ponorogo sangatlah terbantu setelah memanfaatkan perangkat TIK yang tersedia. Sekolah ini memang sudah memiliki beberapa perangkat TIK yang bisa digunakan dalam proses pembelajaran. Semua responden menyatakan bahwa mereka mengajar di kelas dengan menggunakan laptop yang terhubung dengan LCD Projector, sedangkan PC digunakan dalam pembelajaran di laboratorium komputer. Semua ruang kelas di SMPN 5 Ponorogo memang telah dilengkapi dengan LCD Projector yang dipasang secara permanen, meskipun tidak semuanya dalam kondisi baik. Ruangan kelas yang lembab mengakibatkan beberapa LCD Projector menjadi berjamur sehingga kurang maksimal ketika dioperasikan.

\section{Pemanfaatan Sumber Belajar Online}

Saat ini, Indonesia ada di urutan ke 5 negara dengan pengguna internet terbanyak, sebagaimana bisa kita lihat dari Tabel berikut ini. 
Tabel 4. Negara dengan Pengguna Internet Terbanyak (diambil dari http://www.internetworldstats.com/ top20.htm)

\begin{tabular}{|c|c|c|}
\hline No & Negara & $\begin{array}{l}\text { Pengguna Internet } \\
\text { hingga } 30 \text { Juni } 2017\end{array}$ \\
\hline 1 & China & 738.539 .792 \\
\hline 2 & India & 462.124 .989 \\
\hline 3 & Amerika Serikat & 286.942 .362 \\
\hline 4 & Brazil 1 & 39.111.185 \\
\hline \multicolumn{3}{|c|}{ 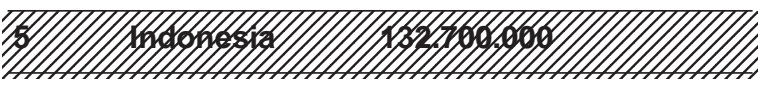 } \\
\hline 6 & Jepang & 118.453 .595 \\
\hline 7 & Rusia & 109.552 .842 \\
\hline 8 & Nigeria & 91.598 .757 \\
\hline 9 & Meksiko & 85.000 .000 \\
\hline 10 & Bangladesh & 73.347 .000 \\
\hline
\end{tabular}

Berdasarkan tabel pengguna internet di dunia tersebut, bisa kita simpulkan bahwa akses internet di Indonesia sudah sangat baik, meskipun tidak seluruh bagian wilayah Indonesia bisa mengakses internet dengan kualitas yang sama baik. Namun demikian, banyaknya wilayah yang sudah terkoneksi dengan internet menjadi suatu keuntungan tersendiri dalam pemanfaatan sumber belajar yang berbasis internet. Internet sangat bermanfaat untuk menunjang proses pembelajaran karena mempunyai keunggulan dibandingkan dengan media komunikasi lainnya. Sebagai perbandingan, untuk menjangkau pengguna sejumlah 60 juta orang, media radio membutuhkan waktu 30 tahun dan media televisi membutuhkan waktu 15 tahun. Untuk menjangkau jumlah pengguna yang sama, media internet membutuhkan waktu yang jauh lebih singkat yaitu hanya 3 tahun (Yanuarti, 2016).

Guru-guru di SMPN 5 Ponorogo sudah terbiasa memanfaatkan beberapa sumber belajar berbasis internet. Salah satunya adalah menggunakan mesin pencari seperti Google untuk mencari referensi terkait dengan materi pembelajaran. Selain itu, mereka juga memanfaatkan portal Rumah Belajar, yaitu fitur Sumber Belajar dan Bank Soal. Sumber
Belajar mereka manfaatkan untuk melengkapi materi pembelajaran, sedangkan Bank Soal mereka manfaatkan sebagai sarana untuk evaluasi. Guna memperoleh materi pembelajaran berupa video, para guru biasa mengakses situs penyedia video seperti YouTube dan mengunduhnya untuk kemudian dipadukan dengan media lainnya. Bagi para guru yang mengampu mata pelajaran bahasa, situs kamus online dirasa sangat membantu karena bisa dimanfaatkan untuk mencari arti dari kata-kata yang dianggap sulit. Bagi guru yang mempunyai kemampuan lebih dalam memanfaatkan TIK, juga memanfaatkan Learning Management System (LMS) untuk membantu proses pembelajaran misalnya Edmodo. LMS seperti ini memungkinkan guru berinteraksi dengan siswa meskipun tidak berada dalam waktu dan tempat yang sama. Memang diperlukan persiapan yang matang dari guru dalam membuat "kelas virtual" ini sehingga dapat diikuti oleh siswa dengan baik. Beberapa guru juga memanfaatkan aplikasi berbasis internet untuk membuat kuis guna meningkatkan motivasi belajar siswa, aplikasi tersebut antara lain adalah Kahoot. Dalam aplikasi tersebut guru harus terlebih dahulu membuat soal dan kunci jawaban, setelah itu siswa mengikuti kuis secara bersama-sama dan hasilnya bisa langsung diketahui siapa pemenangnya. Kuis online semacam ini sangatlah menarik bagi siswa, karena muncul kompetisi diantara para siswa untuk menjadi yang terbaik.

Lingkungan sekolah yang dilengkapi dengan koneksi internet memang mendukung para guru di SMPN 5 Ponorogo untuk memanfaatkan berbagai sumber belajar yang berbasis internet. Selain itu, keberadaan 3 laboraturium komputer juga sangat mendukung pembelajaran yang berbasis jaringan internet, di mana koneksi internet di dalam laboraturium komputer tersebut lebih stabil dibandingkan dengan koneksi internet menggunakan wifi.

\section{Keuntungan Memanfaatkan TIK dalam Pembelajaran}

Guru-guru di SMPN 5 Ponorogo merasakan banyak manfaat yang diperoleh ketika memanfaatkan TIK dalam proses 
pembelajaran, baik pembelajaran di dalam kelas maupun di luar kelas. Adapun manfaat penggunaan TIK dalam pembelajaran menurut guru SMPN 5 Ponorogo adalah: 1) memudahkan guru dalam kegiatan pembelajaran; 2) menjadikan siswa lebih mudah memahami materi yang disampaikan; 3) guru melakukan persiapan satu kali saja, namun bisa dimanfaatkan untuk beberapa kelas; 4) menjadikan pembelajaran lebih menyenangkan; 5) siswa menjadi lebih tertarik mengikuti pembelajaran; 6) meningkatkan motivasi belajar siswa; 7) menjadikan pembelajaran lebih efektif dan efisien; 8) memperluas sumber belajar; 9) menambah wawasan guru dan siswa dalam menggunakan perangkat TIK, dan 10) menjadikan pembelajaran menjadi lebih berkesan sehingga tidak mudah dilupakan.

\section{Hambatan pemanfaatan TIK dalam Pembelajaran}

Pemanfaatan TIK dalam pembelajaran sangatlah ideal apabila didukung oleh sumber daya manusia dan sarana prasarana (Istiyarti dan Purnama, 2014). Keterbatasan kualitas sumber daya manusia dan sarana prasarana tentu saja akan menjadikan pemanfaatan TIK dalam pembelajaran kurang optimal. Beberapa hambatan yang dihadapi oleh guruguru di SMPN 5 Ponorogo dalam memanfaatkan TIK untuk pembelajaran adalah: (1) keterbatasan sarana yang dimiliki oleh siswa, di mana tidak semua siswa bisa mengakses internet di luar sekolah; (2) koneksi internet sekolah (wifi) yang kurang stabil; (3) tidak memadainya jumlah sarana prasarana dibandingkan dengan jumlah pengguna yang meliputi guru dan siswa; (4) beberapa peralatan pendukung seperti LCD Projector sudah tidak bisa digunakan karena rusak; (5) server lokal bantuan dari Pustekkom-Kemendikbud belum bisa dimanfaatkan karena belum disetting dan tidak disertai buku panduan pemanfaatan atau tutorial; (6) sekolah belum memiliki genset sehingga apabila aliran listrik padam semua peralatan elektronik menjadi tidak bisa digunakan; (7) beberapa guru memiliki kemampuan yang masih rendah dalam memanfaatkan TIK; dan (8) aplikasi Bank
Soal belum bisa dimanfaatkan oleh siswa karena banyak terjadi duplikasi akun siswa sehingga menyulitkan guru dalam memilah akun mana yang aktif.

Berdasarkan hasil penelitian, hambatan berupa sarana dan prasarana di SMPN 5 Ponorogo meliputi keterbatasan jumlah peralatan, koneksi internet yang tidak stabil, tidak memiliki pembangkit listrik cadangan sehingga ketergantungan dengan aliran listrik dari PLN sangat tinggi, dan beberapa peralatan kondisinya sudah tidak layak pakai. Hambatan dari sisi sumber daya manusia adalah adanya beberapa guru yang kemampuannya dalam menggunakan TIK masih rendah.

\section{Dukungan dari Kepala Sekolah terhadap pemanfaatan TIK dalam Pembelajaran}

Kepemimpinan kepala sekolah sebagai seorang leader merupakan salah satu faktor yang mempengaruhi kinerja guru dan pada akhirnya turut menentukan kualitas pembelajaran di sekolah. Disebutkan bahwa gaya kepemimpinan kepala sekolah mempengaruhi kinerja guru, selain budaya sekolah. dan disiplin guru (Suleman dan Ruliaty, 2016). Ada pendapat senada yang menyatakan bahwa kepemimpinan kepala sekolah berpengaruh postif dan signifikan terhadap kinerja guru (Ridho dkk, 2018). Kepala sekolah selaku pimpinan di SMPN 5 Ponorogo sangat akomodatif terhadap perkembangan TIK khususnya yang terkait proses pembelajaran. Sebagai wujud perhatian terhadap pentingnya TIK dalam pembelajaran, Kepala SMPN 5 Ponorogo membuat kebijakan bahwa seluruh guru diwajibkan untuk memanfaatkan TIK dalam proses pembelajaran. Selain mewajibkan penggunaan TIK dalam pembelajaran, Kepala SMPN 5 Ponorogo juga sering melakukan pelatihan internal guna berbagi pengalaman dan pengetahuan baru antar sesama guru. Pelatihan ini berguna untuk meningkatkan literasi digital para guru, sebagai bekal menghadapi perkembangan TIK yang semakin pesat. Sebagai bentuk dukungannya, Kepala Sekolah selalu mengawal sendiri setiap pelatihan yang diikuti oleh para guru, mulai dari awal hingga akhir 
pelatihan. Besarnya dukungan dari Kepala Sekolah tersebut telah menjadikan motivasi belajar dari para guru meningkat.

\section{Kegiatan pembelajaran yang memanfaatkan TIK}

Berdasarkan hasil wawancara dan kuesioner, proses pembelajaran di SMPN 5 Ponorogo secara garis besar sudah memanfaatkan TIK. Pemanfaatan TIK ini terdapat dalam 3 kegiatan pembelajaran, yaitu pendahuluan, inti, dan penutup.

\section{Kegiatan Pendahuluan}

Pada kegiatan pendahuluan, guru-guru terlebih dahulu merevieu materi pembelajan pertemuan sebelumnya yang disampaikan menggunakan bantuan laptop serta $L C D$ projector. Setelah merevieu materi pembelajaran sebelumnya, guru memberikan apersepsi dengan menayangkan video pendek yang diperoleh dari portal Rumah Belajar maupun sumber-sumber lainnya. Tidak lupa guru memberikan motivasi kepada siswa dengan cara mengaitkan materi yang akan dipelajari dengan kehidupan sehari-hari serta menyampaikan tujuan pembelajaran yang harus dicapai dengan menggunakan media presentasi seperti Microsoft PowerPoint. Beberapa guru juga memberikan pre test guna mengetahui seberapa besar tingkat penguasaan materi siswa sebelum mengikuti proses pembelajaran.

\section{Kegiatan Inti}

Pada kegiatan inti ini, guru mengawali pembelajaran dengan menayangkan video terkait materi disertai dengan penjelasan, siswa diminta untuk menyimak tayangan video dan mencatat hal-hal yang dirasa penting. Selanjutnya guru membagi kelas menjadi 6 atau 7 kelompok dan setiap kelompok diberi tugas untuk mendiskusikan permasalahan terkait dengan materi yang disampaikan. Selanjutnya kelompok diminta untuk mempresentasikan hasil diskusinya dengan menggunakan peralatan pendukung yang tersedia, meliputi laptop dan $L C D$ Projector. Peran guru dalam diskusi adalah sebagai moderator sekaligus memberikan koreksi apabila ada kekeliruan terkait dengan materi. Beberapa guru memiliki strategi yang berbeda terkait dengan kegiatan pembelajaran yang memanfaatkan TIK, di mana siswa terlebih dahulu diberikan tugas untuk mengunduh materi dari internet terkait dengan materi pembelajaran untuk kemudian didiskusikan secara kelompok di kelas.

\section{Kegiatan Penutup}

Pada kegiatan penutup, guru akan memberikan kesimpulan dari diskusi yang telah dilakukan sekaligus sebagai kesimpulan dari kegiatan pembelajaran yang telah dilakukan. Kesimpulan pembelajaran ini ditayangkan menggunakan laptop dan $L C D$ Projector sehingga seluruh siswa bisa menyimak dan diikuti dengan melakukan post test dengan tujuan mengetahui perubahan tingkat penguasaan siswa terhadap materi. Apabila diperlukan, guru juga memberikan pengayaan terhadap materi yang belum dikuasai oleh siswa. Sebelum memberikan tugas untuk pertemuan selanjutnya, terlebih dahulu guru melakukan relaksasi dengan mengajak siswa untuk menyaksikan video yang menyenangkan dan menghibur.

\section{TIK dalam Pembelajaran untuk Meningkatkan Motivasi Belajar Siswa}

Seluruh responden dalam penelitian ini menyatakan bahwa siswa-siswa memiliki motivasi belajar yang lebih tinggi ketika mengikuti pembelajaran yang memanfaatkan TIK dibandingkan dengan pembelajaran konvensional tanpa menggunakan TIK. Tingginya motivasi belajar siswa ketika mengikuti pembelajaran yang memanfaatkan TIK bisa dilihat dalam proses pembelajaran sehari-hari. Adapun ciri-ciri dari tingginya motivasi belajar siswa antara lain: tekun dalam belajar baik di sekolah maupun di rumah, pantang menyerah ketika menghadapi kesulitan, semangat dalam mengikuti kegiatan pembelajaran, berusaha menyelesaikan tugas meskipun di luar jam pembelajaran (Aritonang, 2008).

Ketika mengikuti proses pembelajaran yang memanfaatkan TIK, siswa SMPN 5 Ponorogo menunjukkan respon positif, antara lain: antusias, bersemangat, fokus, rasa ingin tahu yang tinggi, dan aktif dalam mengikuti 
pembelajaran. Respon ini lebih positif dibandingkan dengan respon siswa ketika mengikuti pembelajaran konvensional. Sebagaimana disampaikan sebelumnya, motivasi hanyalah salah satu faktor yang mempengaruhi prestasi belajar siswa. Siswa SMPN 5 Ponorogo memiliki hasil belajar yang bermacam-macam, meskipun sudah memanfaatkan TIK dalam proses pembelajarannya. Faktor lain yang mempengaruhi hasil belajar antara lain adalah tingkat kesulitan materi. Namun demikian, seluruh responden menyatakan bahwa sebagian besar siswa mengalami peningkatan hasil belajar setelah mengikuti pembelajaran dengan memanfaatkan TIK.

\section{SIMPULAN DAN SARAN}

\section{Simpulan}

Seluruh guru di SMPN 5 Ponorogo sudah memiliki laptop pribadi yang digunakan untuk membantu pembelajaran di kelas, dan dipadukan dengan LCD Projector milik sekolah. Semua guru juga sudah memanfaatkan TIK dalam proses pembelajaran meskipun dengan frekuensi yang berbeda-beda tergantung kebutuhan. Hambatan terbesar yang dihadapi oleh guru dalam memanfaatkan TIK adalah keterbatasan jumlah peralatan serta beberapa peralatan kondisinya sudah tidak normal. Hambatan lainnya adalah koneksi internet yang tidak stabil serta sekolah belum memiliki pembangkit listrik cadangan yang mengakibatkan ketergantungan dengan aliran listrik dari PLN sangat tinggi. Adapun hambatan dari sisi sumber daya manusia adalah beberapa guru yang kemampuannya dalam menggunakan TIK masih rendah. Pemanfaatan TIK dalam pembelajaran di SMPN 5 Ponorogo terbukti mampu meningkatkan motivasi belajar siswa dibandingkan dengan pembelajaran tanpa menggunakan TIK.

\section{Saran}

Guna mendukung pembelajaran yang memanfaatkan TIK, pihak sekolah perlu melakukan perbaikan dan perawatan berkala terhadap peralatan-peralatan TIK yang kondisinya kurang baik. Selain itu, sekolah juga perlu menyediakan pembangkit listrik alternatif (genset) sebagai langkah antisipasi apabila pasokan listrik dari PLN padam. Kapasitas dan koneksi internet di lingkungan sekolah juga perlu ditingkatkan guna mendukung proses pembelajaran yang berbasis online. Meskipun beberapa guru memiliki kemampuan menggunakan TIK yang masih rendah, mereka memiliki semangat belajar yang tinggi sehingga pihak sekolah bisa memfasilitasi mereka dengan pelatihan atau peer teaching untuk meningkatkan literasi TIK mereka. Pendampingan dari Pustekkom juga sangat diperlukan terutama dalam hal pemanfaatan server lokal, sehingga mampu dimanfaatkan secara optimal.

\section{PUSTAKA ACUAN}

\section{Buku}

Reynold, D. R. (2010). Cerdas dan Terampil Teknologi Informasi dan Komunikasi. Jakarta: Pusat Perbukuan, Kemendiknas.

Pustekkom. (2016). Pedoman Implementasi Penerapan Model Pembelajaran Inovatif. Tangerang Selatan: PustekkomKemendikbud.

\section{Jurnal/Prosiding/Disertasi/Tesis/Skripsi}

Aritonang, K. T. (2008). Minat dan motivasi dalam meningkatkan hasil belajar siswa. Jurnal Pendidikan Penabur No. 10.

Dewi, S. Z. dan Hilman, I. (2018). Penggunaan TIK sebagai sumber dan media pembelajaran inovatif di Sekolah Dasar. Indonesian Journal of Primary Education Vol 2, No 2. Bandung: UPI.

Ismaniati, C. (2010). Penggunaan Teknologi Informasi dan Komunikasi dalam Peningkatan Kualitas Pembelajaran. Jurnal Universitas Negeri Yogyakarta. http://staffnew.uny.ac.id/ upload/131656344/penelitian/ Penggunaan+Teknologi+Informasi+ dan+komunikasi+dalam+peningkatan+kualitas+ pembelajaran.pdf (diunduh 5 Februari 2018).

Istiyarti dan Purnama, E. K. (2014). Pemanfaatan TIK untuk Pembelajaran. Jurnal Kwangsan Vol. 2 - Nomor 1. 
Miru, A. S. (2009). Hubungan antara Motivasi Belajar terhadap Prestasi Belajar Mata Diklat Instalasi Listrik Siswa SMK Negeri 3 Makassar. Jurnal Medtek Volume 1 Nomor 1. http:// ele k t ro.un m.ac.id/jurnal/ Jurnal_MEDTEK_VOL.1.\%20No.\%201_2009/ Alimuddin\%20SM.pdf (diunduh 9 Januari 2018).

Ridho, T., Wulan, H. S. dan Wahyono, E. H. (2018). Pengaruh Budaya Organisasi, Kepemimpinan Kepala Sekolah dan Kompetensi Guru Terhadap Kinerja Guru dengan Kepuasan Kerja sebagai Variabel Intervening (Studi Kasus pada Guru SMK Teuku Umar Semarang). Journal of Management Vol 4, No 4.

Suleman, S. dan Ruliaty. (2016). Pengaruh Gaya Kepemimpinan Kepala Sekolah, Budaya Sekolah, dan Disiplin Guru Terhadap Kinerja Guru pada Sekolah Menengah Kejuruan (SMK) Negeri I Jeneponto. Jurnal Competitiveness Vol. 10, Nomor 2.

Triyanto, E., Anitah,S. dan Suryani, N. (2013). Peran Kepemimpinan Kepala Sekolah dalam Pemanfaatan Media Pembelajaran sebagai upaya Peningkatan Kualitas Proses Pembelajaran. Jurnal Teknologi Pendidikan Vol 1, No 2.

Warsihna, J. (2012). E-Learning Melalui Portal Rumah Belajar. Jurnal Teknodik Vol. XVI No. 2.

Warsihna, J. (2013). Pemanfaatan TIK untuk Pendidikan (e-learning) di SMP. Jurnal Teknodik Vol. 17 Nomor 1.

Widoyoko, E. P. (2009). Kompetensi Mengajar Guru IPS SMA Kabupaten Purworejo. http:// www.umpwr.ac.id/publikasi-ilmiah/347kompetensi-mengajar-guru-ips-smakabupaten-purworejo.html (diunduh 5 Maret 2018).

Wijaya, M. (2007). Pemanfaatan Teknologi Informasi dan Komunikasi dalam
Pembelajaran. Jurnal Pendidikan Penabur No 08/Th VI.

\section{Lain-lain}

Internetworldstats. (2017). Top 20 Countries with the Highest Number of Internet Users. http:// www.internetworldstats.com/top20.htm (diunduh 6 Februari 2018).

Prensky, M. (2017). Digital Natives, Digital Immigrants. http://www.marcprensky.com/ writing/ Prensky\%20-\%20Digital\%20Natives, \%20Digital\%20Immigrants\%20-\%20Part1.pdf (diunduh 22 Oktober 2018).

Pustekkom. (2016). Keputusan Kepala Pustekkom Nomer: 3734/12.3/KP/2016 tentang Penetapan Sekolah Model Pembelajaran Inovatif Berbasis TIK dengan Memanfaatkan Rumah Belajar. Tangerang Selatan: PustekkomKemendikbud.

Siahaan, S. (2009). Pemanfaatan Teknologi Informasi dan Komunikasi (TIK) dalam Pembelajaran (Modul Pelatihan Pengembangan dan Pemanfaatan Konten Jardiknas). Tangerang Selatan: Pustekkom, Depdiknas.

Sudrajat, Akhmad. (2008). Teori-teori Motivasi. http://akhmadsudrajat.wordpress.com/2008/ 02/06/teori-teori-motivasi/ (diunduh 9 Januari 2018).

Yanuarti, R. (2016). Modul Pemanfaatan Sumber Belajar Online. Tangerang Selatan: Pustekkom, Kemdikbud.

\section{Ucapan Terima Kasih}

Terima kasih penulis ucapkan kepada kepala sekolah, dewan guru, murid-murid serta keluarga besar SMPN 5 Ponorogo, tidak lupa juga kepada mitra bestari dan penyunting jurnal Teknodik, serta seluruh pihak yang telah membantu menyusun artikel ini. 